\title{
Breaking of Chiquinha Gonzaga In The History Of Music: Inclusion Of The Female Creative Power*
}

Lilian Maria TONELLA TüZüN**

Tonella Tüzün, L.M. (2019). Breaking of Chiquinha Gonzaga In The History Of Music: Inclusion Of The Female Creative Power, Yedi: Sanat, Tasarım ve Bilim Dergisi, Kış 2019 (21), s. 53-59.

Araştırma Makale / Research Article

\section{Abstract}

Until the late nineteenth century, the rarely seen female composers in history of music had musical education supported by their fathers until the age of marriage when the focus had to turn into a new familiar nucleus. However, only the female artist, who had achieved economic freedom, was able to develop her creativity. Chiquinha Gonzaga (1847-1935) is one of those exceptional cases that managed not only to enter the History of Music but also to change the parameters of Brazilian music. The aim of this study is focused on the role of her works within the conservative society of Rio de Janeiro and her influence on contemporary male composers. The study concludes that her artistic creativity broke rules of the conservative society of her time, not allowing herself to be a victim of the system.

Keywords: Chiquinha Gonzaga, Woman composer, Brazilian music, Creative power, Female inclusion

\section{Müzik Tarihinde Chiquinha Gonzaga Kırılması: Kadının Yaratıcı Gücü}

\section{Özet}

Müzik tarihinde XIX. yüzyıla kadar nadir rastladığımız kadın besteciler evlenene kadar babaları tarafından desteklenen müzik eğitimlerini evlilikle beraber bırakarak ailelerine odaklanmışlardır. Ancak istisnai olarak, ekonomik özgürlüğünü elde etmiş kadın sanatçı yaratıcılığını geliştirebilmiştir. Chiquinha Gonzaga (1847-1935), Brezilya müziğinin parametrelerini değiştirmeyi başararak, müzik tarihinde yer almış bu nadir kadınlardan biridir. Bu çalışmada, Gonzaga'nın eserleriyle Rio de Janeiro'nun muhafazakar toplumu ve erkek besteciler üzerindeki etkisi incelenmiş, bestecinin sanatsal yaratıcılığının muhafazakar toplum kurallarını hiçe saydığı ve kendini sistem tarafından kurban edilmeye izin vermediği sonucuna varılmıştır. 


\section{Introduction}

Thinking about the history of women in music is to consider the history that determinates them in music. The patriarchal and conservative societies excluded women musicians for reasons that the blind tradition imposed for thousands of years. This question covers a social complex inhabited by women and men, their economic roles, their insertion in society as citizens and the inherent interests of their respective classes. Until the late nineteenth century, the rare names of female musicians in history of music had family support till the age of marriage, then they should focus on the new family nucleus formed by husband and children. This is because the music for man could be a profession, however, for woman only a hobby. Exceptions have occurred in cases where the female artist of dominant character had become economically active. Two cases can be examined and taken as referential examples for other women musicians. The musical literature of the nineteenth century investigated the German Mendelssohn and Schumann families and explored the ladies Fanny Mendelssohn (1805-1847) and Clara Wieck Schumann (1819-1896) as sister and wife of the famous composers Felix Mendelssohn (1809-1847) and Robert Schumann (1810-1856) consecutively. Fanny and Clara were disciplinarily educated and encouraged since early years by their father to play piano well and compose high quality music. However, the extensive bibliography of the great composers Felix and Robert puts Fanny and Clara as merely as sister and wife, illustrating how the female creative power was put in the adjuvant situation in name of their male relatives. In Fanny's case, father and brother prevent her from composing advance of her youth. After her engagement with Wilhelm Hensel (1794-1861), she restricted her work to her house. Fanny had no choice but to submit to the male figures of her brother, father and husband. Besides that, many of her compositions were published in name of her brother Felix, exactly because she was woman (Baltonado, 2017).

Already Clara was not led by social submission as Fanny, at least in part. As an exceptional popular artist at age fifteen and encouraged by her father Friedrich Wieck (1785-1873), she earned money giving concerts. In that time, Friedrich was one of the most respectable teachers and music dealer, and used to receive private students from other regions in his home. Falling in love with one of his students and forbidden to relate, Clara runs away from home to marry Robert. After eight consecutive births and with only one piano in the house, which
Robert worked, Clara had to dedicate to her new nucleus familiar, rarely working on the piano. Only after Robert's death Clara began playing the piano again due to financial difficulties and remained on stage until her seventy-two years old (Silva , 2011). Absolutely, this economic experience in early age gave her impulse and confidence to continue her career until the end of her life. Clara demonstrated autonomy and contempt for her father but not for her husband - she surrendered to his geniality. In both cases, it is noted that economic independence made differences in the professional life of the female musicians. While Fanny had to interrupt her activities with music, Clara continued until the end of her life due to her economic emancipation. It is possible to recognize around the world and different epochs thousands of Fannyes and Claras giving up or struggling for their careers.

One of those examples was born in Rio de Janeiro, Brazil, in the same year that Fanny died in Germany. As the focus of this study, Chiquinha Gonzaga (1847-1935) was another case of the rare female musicians who entered in the History of $\mathrm{Mu}$ sic.

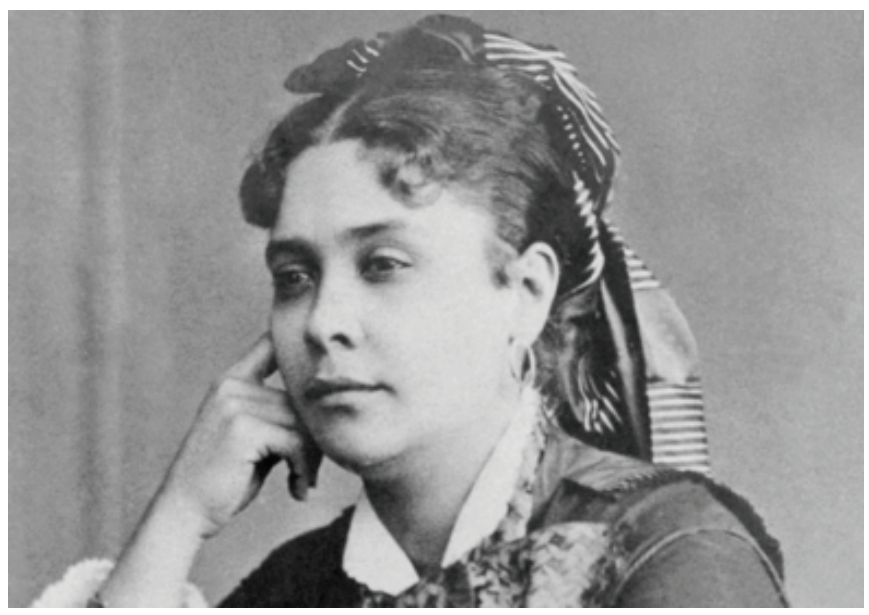

Figure 1. Chiquinha Gonzaga in 1876 at the age of 29 (Freitag, 1986, p. 23).

She grew up in a society where the religious values and customs were imported from the northern hemisphere. Deserves to be noted that the female education in the New World followed the European mentality: learning was directly related to the insertion and interaction of women with the social environment. Essential factors for a good marriage. In the domestic education were included the cultivation of dance, singing, conversation, etiquette, music and piano classes. These good manners would ensure a suitable husband - choice usually 
delegated to the father (Bento, 2018). In Chiquinha's case, her father gave support in the music education until the age of sixteen (1863) when she had to marry to the rich mariner Jacinto Ribeiro do Amaral (1839-?), eight years older than her. Although, she was a gifted musician, who loved to write melodies and play the piano in front of others. The marriage did not last long. Chiquinha diverged with her spouse due to her intransigent personality and her willingness to always be playing the piano. Although, Jacinto did not like music or hear the sound of the piano, and to make matters worse, he considered to be inappropriate for a woman to sit on the piano bench. The mismatch of the couple broke out with the ultimatum from her husband: me or the music'. With the answer 'I do not understand life without harmony', Chiquinha started a long history of struggle to keep on in the prejudiced society of Rio de Janeiro (Diniz, 1984, p. 67). She was able to support herself by giving piano lessons, selling her scores and playing piano in public places. With this effort, she gradually approached Rio de Janeiro's popular music circles and gained appreciation. In those musical circles, Chiquinha met the 'father of the choro' Joaquim Antonio da Silva Callado (1848-1880) how gave her a new perspective of musical education end opened new opportunities of work. She started to play and write pieces for the musical group Choro Carioca, which became renowned between the musicians (Tonella Tüzün, 2017). Between the musicians were free slaves exploring a new kind of popular music: European melodies mixing with Afro-Brazilian rhythms.

Deserves to be highlighted that, at this time, many people supported the abolition of slavery as social and political causes. Precisely at the moment when Chiquinha beginning to be part of the city life, the abolitionist issue was a common subject between people. In this context, she acted several times in artistic events to raise funds to the Freedom Confederation for the emancipation of the slaves and it is known that she even sold her scores on the streets to buy the freedom of the gifted slave musician Zé da Flauta (Verzoni, 2011).

Figure 2 shows the ambiance in which the Brazilian popular music was emerging. It exposes the profile of the lower classes of Rio de Janeiro, generally the public that admire her musical ideas and vice versa.

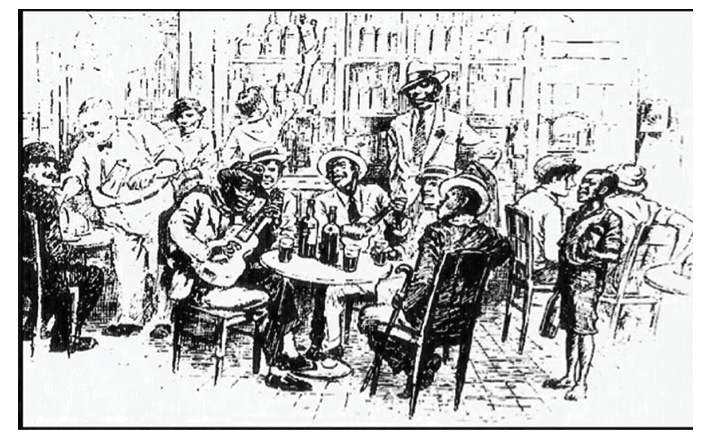

Figure 2. Choro wheel by cartoonist Seth (Chorão, 2011).

In those circles, the composer began to gain financial independence as a musician; the piano lessons are no longer her economic source, and she indulges in more complex compositions focusing on a new audience. On the other hand, the active participation of Chiquinha in artistic circles, bohemians, politicians and even police, in a city that did not exceed four hundred thousand inhabitants, made her a public figure exposed to all kinds of comments - from praise in the press to gossips whispered by families. Defamations had an important moralizing function: her behavior was not example for the other women (Rocha, 2006).

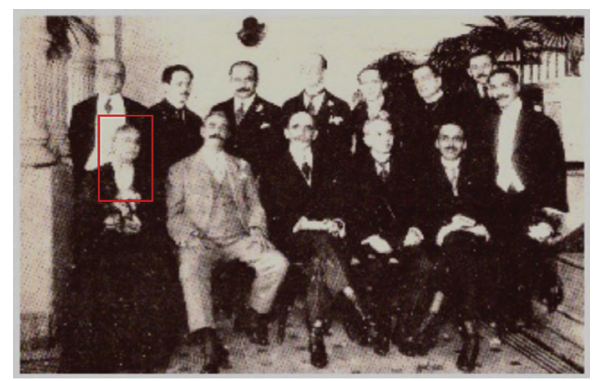

Figure 3. Chiquinha Gonzaga with theatrical authors at the reception of the Portuguese pianist Vianna da Mota in 1926 (Diniz, 1984, p. 258).

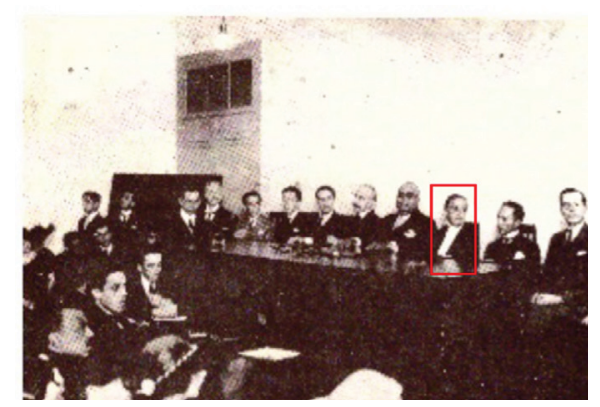

Figure 4. Chiquinha Gonzaga in the Brazilian Society of Theatrical Authors in reception to the Portuguese writer Júlio Dantas (Diniz, 1984, p. 258). 
Leaving aside the defamations and without fear, she was a pioneer in copyright protection and co-founder of the Brazilian Society of Theatrical Writers. The financial gains brought credibility and leadership in her circle, formed for almost all men. The musician is an example of how the emancipation of women redirected the criterion of national music. In other words, her freedom freed the Brazilian music. And still more, she was able to go much further than other women of her time, becoming the second female orchestra conductor of the world ${ }^{1}$ and first in the American continent.

\section{Method}

The study took as bibliographic reference the example of Fanny Mendelssohn and Clara Schuman to illuminate how the women composers were excluded or included in the history. From the cited references, the study focused on the case of inclusion of the composer Chiquinha Gonzaga, highlighting works that became immortalized within the History of Music. Despite being found in literary review over two thousand works by the composer, this study opted to have chosen three of them: 'The court in the countryside' (A corte na roça), 'Accursed' (Maldito) and 'Cut-jackfruit' (Corta-jaca). These three examples are intrinsically linked to the city of Rio de Janeiro and out of the moral convention of its society. Therefore, for better understanding of the subject, this study also deals with the local historical feature.

For this purpose, the descriptive analysis was used to summarize and interpret the previously determined theme (Yıldırım \& Şimşek, 2011, p. 224). In the analysis, data collection techniques were used to describe literature research. In the documentary screening carried out in the data collection process were reviewed files, articles, books, biographies and internet sites (Karasar, 2017, p. 229).

\section{Findings and Comments}

Composers are intrinsically linked to the region in which they live, for this reason, it is imperative to take into consideration the historical and social factors of the native land for better assimilation of the composer Chiquinha Gonzaga. Rio de Janeiro was the capital of Brazil and the heart of significant political and historical events during the composer's life. In the beginning of the nineteenth century, Rio de Janeiro becomes the capital of the kingdom, by the transfer of the Portuguese 1 Elfrida Andrée (1841-1929) was the first Swedish woman organist and the first woman to conduct a symphony orchestra in the world. She is known equally well in Sweden as a pioneer advocate for the rights of women. court to Brazil and goes through great artistic transformations: constructions of libraries and museums, artistic missions and aristocratic parties in the European styles. However, the Portuguese aristocracy was fundamentally mixed with the slavery system. In the middle of the nineteenth century, the city of Rio de Janeiro underwent again for major transitions. The inevitable urbanization gained an intermediate social class, formed by free slaves, due to the end of the slave trade. This new layer of the population grew rapidly and mainly boosted the emergence of popular musical theater, rather than the lyrical and dramatic, preferred by elites (Mello, de Camargo Piedade, \& da Silva Schneider, 2010). In the period before the abolition of slavery, the high society was defending European values with the sound of African drums. Still, in other words, while waltzes and polkas were played at family gatherings and salons, lun$\mathrm{du}^{2}$ wheels were danced on the corner of streets. The miscegenated society, or the lower class was breaking definitely with European values by encouraging the emergence of a national culture.

As for the musical aspect, the eccentric rhythmic music began to be heard gradually in the stages of the theatres and surprisingly, in the aristocratic parties. It was in these places that Chiquinha Gonzaga manage to left her mark and entered forever in the History of Music. With the purpose of verifying this reality, three works are treated in this study: 'The court in the countryside', 'Accursed' and 'Cut-jackfruit'.

'The court in the countryside': The theatre was a need for the elite of that time, which longed for presentations that could c ompete with those made in Europe, however with national themes and original scenarios. Among the comic genre, the operetta becomes quite popular. Following the French example of the Theatre des Boufes Parisiens, the operetta style came to the stages of Rio de Janeiro in 1859. The genre was easily adopted in the musical theatres by the local public, especially due to its comedy, joy, tropical scenario and informality which were reflected in the character of the Brazilians. The emergence of the musical theatre brought an aesthetic conception change and a significant attendance increase, with financial benefits for actors, authors and producers (Souza, 2006). The changes in the aesthetic conception occurred for following reasons: for some of the intellectual groups, the true National Theatre should contain genres such as drama and tragedy; for others,

2 According to Lima (1972), lundu is a dance of African origin and became song with the time. Usually, lundu has the following characteristics: major tonality, binary compass, punctuated rhythms, besides a literary text, in which there is always a burlesque censure. 
the legitimately Brazilian was in the popular taste, in the Afro dances, in the easy laughter and in the joyful melody that was heard in the streets of Rio de Janeiro (Bento, 2018, p. 127). Chiquinha was able to create scores that corresponded with all this popular universe: unique melodies, bouncy rhythms and the inclusion of original instruments of the choro wheels, demonstrations of the sensuality of the Afro-Brazilian dances and texts criticizing society and politics.

At the beginning of the stage career, Chiquinha had to test more than her talent; she had to prove that a woman was also able to create scores for the theatre and, even more daring, conducting an orchestra formed only by men. She became the first woman in the Americas to achieve this feat.

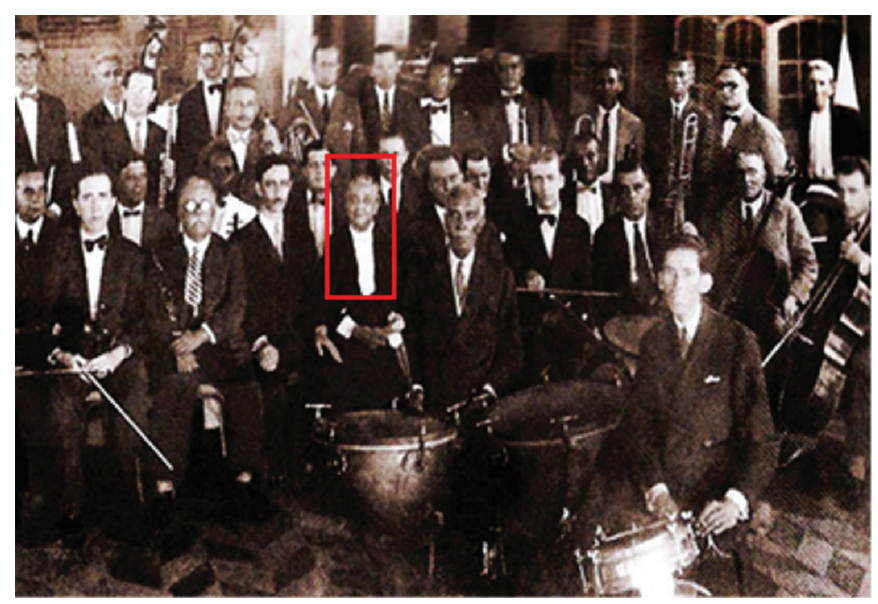

Figure 5. Chiquinha Gonzaga’s orchestra (Diniz, 1984).

The operetta 'The court in the countryside' was premiered in 1885 at the Imperial Prince Theatre and defended the end of slavery by adapting the servant characters as no more slaves. It was the anticipation of the abolition that occurred three years after the work's premiere. Besides that, she treated with humour and criticism the aristocracy, which gave her back grievously censure. The aristocracy thought immoral the sensual dances and could not absorb the fact that a woman in a skirt stood on stage to conduct men musicians.

Definitely, the theatre was the vehicle of the consecration of the composer, she effectively made her name dear to the public and respected by critics despite being a woman (Bento, 2018). Her prolific production has more than seventy scores for theatre, reaching an unquestionable success.

'Accursed': In 1889, one year after the abolition and the year of the Proclamation of the Republic of Brazil, Chiquinha organized another musical event that irritated again the conservative circles. She conducted the original concert of one hundred guitarists and named it with the adjective accursed. It was the way that the instrument was called by the more conservatives at the time. The concert was a tribute to the composer Carlos Gomes (1836-1896) and was performing at the São Pedro de Alcântra Theatre.

In fact, the guitar arrived in Brazil with the Portuguese Jesuits still in the seventeenth century, who used it to catechize the Indians during the evangelization. In two centuries, the instrument became widely popular in all country, especially between free slaves or descendants of slaves. Usually, the music was joyful, of sensual spirit, fast tempo and in played in vocal accompanying and choro wheels. For this reason, the guitar gained a bad reputation by the same that brought it to the country. According to the Catholic church, the guitar was a darned instrument, because women and men used to dance too closed with its sounds, as seen in the Figure 6 . Considered an instrument of bohemians, the guitar became a symbol of vagrancy and carried this stigma for many years (Mundo do Violão).

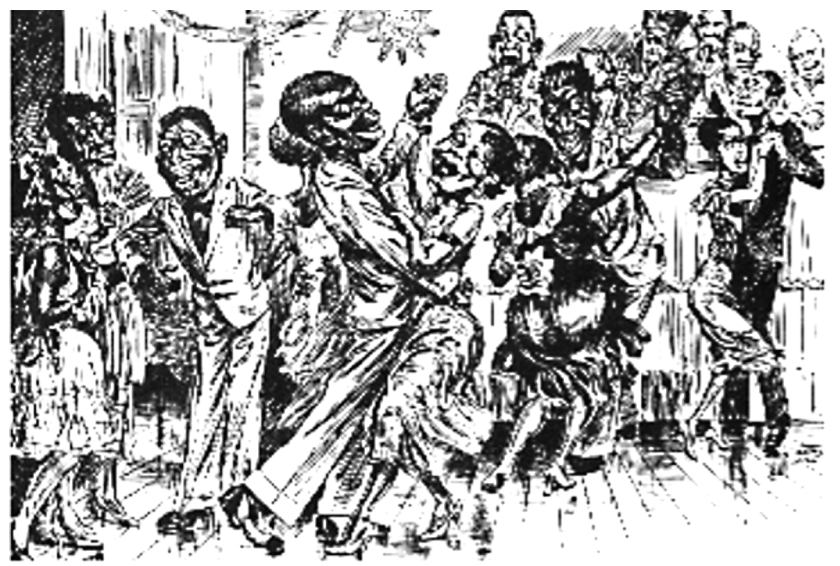

Figure 6. Choro wheel by cartoonist Seth (Chorão, 2011).

This historical case allows to understand why the behavior of Chiquinha was so severely condemned: she was a woman of ill-fame taking part of the Rio de Janeiro Bohemian wheels, writing undeniably bouncy songs and bold titles. Between others, 'Seductive', 'Attractive', 'Accursed'. It was too much of a provocation for a society that still kept its moral codes rigid (Bento, 2018). 
The guitar concert was an important step to unmask the religious hypocrisy imposed and accepted by society. Chiquinha honored the instrument by placing it on the stage of one of the most illustrious theatres in the center of Rio de Janeiro. She was one of the precursors of this respectful instrument's inclusion in Brazil. A fearless act that spurred the emergence of the first schools of guitar in Brazil.

'Cut-Jackfruit': Originally, this work was written by Chiquinha with the name 'Tango Gaucho' for the nationalist operetta 'Zizinha Maxixe' by Machado Careca, premiered in 1895 in the Edén Lavradio Theatre. The author of the operetta wrote the verses for the music popularizing it as 'Cut-Jackfruit' and, the piece was one of the most famous and recorded work by the composer. Throughout history, the work was performed in several stages of cafes and choro wheels before got in the diplomatic halls.

At the beginning of the Republic of Brazil, in 1914, the First Lady Nair de Teffé ${ }^{3}$ had invited a friend Catulo da Paixão Cearense (1863-1946) to play in the guitar together with her in the farewell dinner of the President of the Republic Hermes da Fonseca (1855-1923). Never before the politic audience heard popular music within its receptions; the tradition recommended only European music or local music without nationalistic characteristics. According to the tradition, the guitar was already an offense in itself - the popular instrument was not accepted by dominant class as seen in the 'Accursed' - besides that, there are verses considered obscene and offensive.

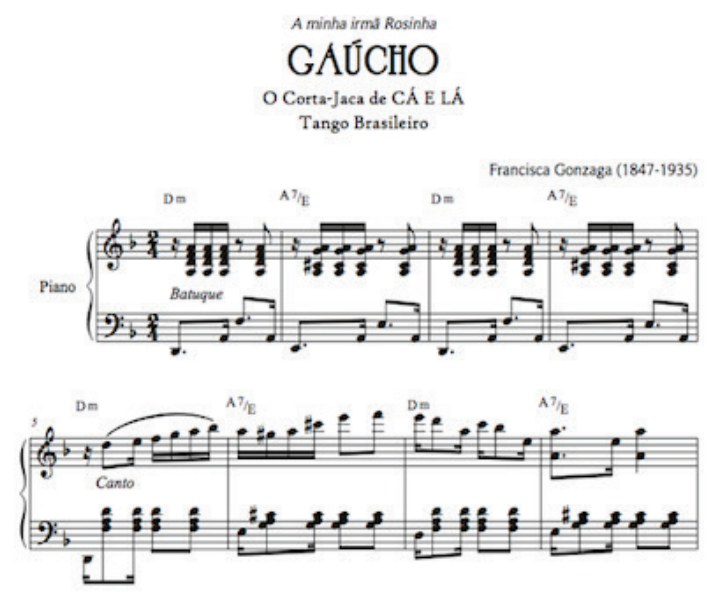

Figure 7. The first bars of the Cut-Jackfruit.

\footnotetext{
3 Nair de Teffé (1886-1981) was the first female caricaturist in the world. Taffé was also painter, actress and writer, and used to mark with boldness her social circles. Like Chiquinha, she stood out as a transgressor of behavioral patterns demanded of the women of her social class. Like Clara Schumann, she had to stop her caricature activities after married the
} President, and only after his death, she could continue until the end of her life.
The event became known as 'the night of the cut-jackfruit' and entered singularly in history. A work written by a woman composer was the reason for political disagreements between the senators and in the newspapers. In the following days, the famous politician and writer Rui Barbosa (1849-1923) made an angry speech in the National Senate, which yielded days of news. Rui Barbosa mentioned cut-jackfruit as 'the lower, coarser and vulgar of all wild dances, the twin sister of the batuque, cateretê and samba' and still 'in the presidential receptions the 'corta-jaca is executed with all the honors of Wagner's music' (Verzoni, 2011)

Incontestably, the inclusion of Chiquinha Gonzaga's music in the high society circle was promoted by another pioneer woman, the First Lady of the Republic. The conscious and audacious, the two Brazilian women marked the history forever: the 'cut-jackfruit style' was giving the first steps of the nationalization of the music. Chiquinha understood perfectly the musical genre and developed wonderfully the rhythm of the new national emblem: the samba. The 'Cut-jackfruit' was a symbol of the female creative power that implied forever the inclusion of a woman composer on the History of Music.

\section{Conclusion}

1) The cases cited show the factors of exclusion or inclusion are directly linked to economic independence. The study concluded that the monetary power achieved by Clara Schumann and Chiquinha Gonzaga guaranteed them more time on the scene than Fanny Mendelssohn.

2) The works 'The court in the countryside', 'Accursed' and 'Cut-jackfruit' chosen in this compilation study, synthesize views on how the female creative power won a conservative society, ascended on male composers and signed a new profile of national aesthetic.

3) Due to a conjuncture of factors - talent, wide creative production, and independent financial power - Chiquinha Gonzaga became the second female orchestra conductor in a world when the equality of men and women was not even taken. At the end of the nineteenth century and beginning of the twentieth century, the Brazilian musician was able to reach the apex of musical activity: to rise to the stage as conductor, breaking with all established rules and becoming the symbol of autocratic power, whose authority was recognized and accepted by all. 
4) It was identified in the literary review of this work that the single writer bibliographical sources about Chiquinha Gonzaga were exclusively written by women. According to the Reference section of this study, it was concluded that there is a tendency and greater interest of women to research on the rare names of female composers who entered to the history of music. In conclusion, the inclusion of female creative power in the history of music is gradually carried out by women researchers.

\section{Bibliotheca}

Acervo Digital. (2014). www.chiquinhagonzaga.com. 102018 tarihinde Chiquinha Gonzaga: http://www.chiquinha gonzaga.com/acervo/partituras/gaucho_ca-e-la_pia no_cifra.pdf adresinden alındı

Baltonado, J. (2017, 9 5). Out of the Shadows: Clara Schu mann, Fanny Mendelssohn, and the Will to Persist. 9 9, 2018 tarihinde https://academicworks.cuny. edu/hc_sas_etds/160. adresinden alındı

Bento, M. L. (2018). Chiquinha Gonzaga e o teatro musical brasileiro do século XIX. (UFMS, Ed.) Revista Eletrô nonica Trilhas da História , 7 (14), 120-137.

Chorão, B. (2011, 01 18). Roda de Choro adega da Lapa. 09 13, 2018 tarihinde Alvaro Marins - Seth: http://alva romarinsseth.blogspot.com/adresinden alındı

da Costa Bento, M. (2018). Chiquinha Gonzaga e o teatro mu sical brasileiro do século XIX. Revista Trilhas da História , 7 (14), 120-137.

Diniz, E. (1984). Chiquinha Gonzaga uma história de vida.Rio de Janeiro: Codecri.

Freitag, L. V. (1986). Momentos da Msica Brasileira. Sao Pau lo: Nobel.

Karasar, N. (2017). Bilimsel Araştırma Yöntemi. Ankara.

Lima, R. T. (1972). Abecê do Folclore. São Paulo: Ricordi.

Mello, M. I., de Camargo Piedade, A. T., \& da Silva Schneider, A. (2010). Colegio de senhoritas: musica original de Chiquinha Gonzaga. In: UDESC (Ed.), Seminario de Estudos de Genero, (pp. 1-11). Santa Catarina.

Mundo do Violão. (s.d.). Violão no Brasil. Acesso em 10 de 2018, disponível em www.mundodoviolao.com.br: http://www.mundodoviolao.com.br/historia/histo ria-do-violao-no-brasil/

Rocha, M. (2006). Chiquinha Gonzaga: transgressao, sucesso e memoria. A relacao entre a compositora e a teoria social do escandalo. IV Encontro Nacional de Pesqui sadores em Jornalismo, (pp. 1-14). Porto Alegre.

Silva , E. M. (2011). Clara Schumann - Compositora X Mulher de Compositores. São Paulo, SP , Brezilya: Ficções.

Souza, S. M. (2006). Um Offenbach tropical: Francisco Correa Vasques e o teatro musicado no Rio de Janeiro da segunda metade do seculo XIX. Historia e Perspecti vas (34), 225-259.

Tonella Tüzün, L. (2017). Brezilya'da Piyano. Ankara: Hacette pe Üniversitesi Ankara Devlet Konservatuvarı-Mü sam.

Verzoni, M. (2011). Chiquinha Gonzaga e Ernesto Nazareth: duas personalidades e dois percursos. . Revista Bra sileira de Música , 24 (1), 155-169.

Yıldırım, A., \& Şimşek, H. (2011). Nitel Araştırma Yöntemle ri. Ankara, Türkiye: Seçkin. 